\title{
Risk of Escherichia coli O157:H7 infection linked to the consumption of beef
}

\author{
${ }^{1,2}$ Premarathne J. M. K. J. K., ${ }^{1}$ New, C. Y., ${ }^{1}$ Ubong, A., ${ }^{4}$ Nakaguchi, Y., \\ ${ }^{5}$ Nishibuchi, M. and ${ }^{1,3 *}$ Son, R. \\ ${ }^{1}$ Department of Food Science, Faculty of Food Science and Technology, Universiti Putra \\ Malaysia, 43400 UPM Serdang, Selangor Darul Ehsan, Malaysia \\ ${ }^{2}$ Department of Livestock and Avian Science, Faculty of Livestock, Fisheries and Nutrition, \\ Wayamba University of Sri Lanka, Makandura, 60170 Gonawila, Sri Lanka \\ ${ }^{3}$ Food Safety and Food Integrity, Institute of Tropical Agriculture and Food Security, \\ Universiti Putra Malaysia, 43400 UPM Serdang, Selangor Darul Ehsan, Malaysia \\ ${ }^{4}$ Faculty of Bioresources and Environmental Sciences, Ishikawa Prefectural University, \\ Nonoichi City, Ishikawa Prefecture, Japan \\ ${ }^{5}$ Centre for South Asia Studies, Kyoto University, 46 Shomoadachi-cho, Yoshida Sakyo-ku, \\ Kyoto 606-8510, Japan
}

\begin{abstract}
Article history:
Received: 13 March 2017

Received in revised form: 25 March 2017

Accepted: 27 March 2017 Available Online: 12 May 2017
\end{abstract}

Keywords:

E. coli $\mathrm{O} 157: \mathrm{H} 7$

Beef

Quantitative microbial risk assessment

DOI:

http://doi.org/10.26656/ fr.2017.3.011

\begin{abstract}
Escherichia coli $\mathrm{O} 157: \mathrm{H} 7$ is a major food-borne pathogen that has resulted in numerous outbreaks around the world. Widespread distribution of the organism in various ecological niches impedes the control measures. This study aimed to detect and quantify E. coli $\mathrm{O} 157: \mathrm{H} 7$ in beef sold in wet markets and hypermarkets in Malaysia and to determine the risk of $E$. coli O157:H7 infection linked to consumption of beef. The $r f b \mathrm{O} 157$ and flic $\mathrm{H} 7$ primers targeted on somatic antigen (O157) and flagellar antigen (H7) respectively of $E$. coli $\mathrm{O} 157: \mathrm{H} 7$ was used for the MPN-PCR method. A total of 99 beef samples were collected from local wet markets and hypermarkets. The highest $E$. coli $\mathrm{O} 157: \mathrm{H} 7$ contamination rate was observed in beef samples collected from wet markets (89.50\%), whereas the contamination rate in hyper market A and B were compratively low (35.35 and $20 \%$ respectively). However, the microbial load was highest in the beef samples from hypermarket A (1100 MPN/g) while E. coli O157:H7 bacterial load in beef samples from hypermarket B and wet market ranged from 3 to $93 \mathrm{MPN} / \mathrm{g}$ and 3 to 240 MPN/g, respectively. Using the Quantitative Microbial Risk Assessment (QMRA) approach the risk was estimated incorporating the findings of the prevalence study and predictions based on home storage, cooking and consumption patterns. Three different exposure pathways were investigated to estimate the risk associated with contaminated beef and Monte Carlo simulation was used to determine the level of uncertainty. The developed model predicated that consumption of contaminated beef can be accountable for 1.83E+06 E. coli $\mathrm{O} 157: \mathrm{H} 7$ cases per year in Malaysia. The reliability of the model, data gaps and further research needs, is discussed. Through continuous improvement Quantitative Microbial Risk Assessment provides valuable insight into controlling and prevention strategies.
\end{abstract}

\section{Introduction}

According to the surveillance data of Malaysian Health Ministry, 50.33 cases per 100,000 people food and water-borne diseases were reported in Malaysia in year 2016 (MOH, 2016). Among the food and water-borne diseases, incidence of food poisoning cases were most prevalent with accounting for 47.34 cases per 100,000 populations in 2016 (MOH, 2016). However, the true burden of food-borne diseases in Malaysia need to be investigated (Lim, 2002). Under-diagnosis and under-reporting of food-borne disease in developing countries mainly resultant due to inadequate investigation and surveillance systems (Beuchat, 1998).

The majority of $E$. coli strains naturally inhabit the intestinal tract of the warm-blooded animals including humans, and most strains are non-pathogenic (Bell and Kyriakides, 1998). Every year more than E.coli O157:H7 estimated to cause around 73,000 illness and 250 deaths in United States (Newell et al., 2010). E. coli $\mathrm{O} 157: \mathrm{H} 7$ has emerged as a key foodborne pathogen that leads to foodborne disease outbreaks and sporadic cases in people around the globe (Griff 
and Boyce, 1998; Woodward et al., 2002). E. coli $\mathrm{O} 157 . \mathrm{H} 7$ is a highly virulent strain that is categorised under the enterohemorrhagic E. coli (EHEC) which also referred to as verocytotoxin producing $E$. coli (VTEC) or Shiga-like toxin producing E. coli (STEC) (Meng et al., 2007). The first public health significance of E. coli O157.H7 traced back to 1982, after reporting two unfamiliar enteric outbreaks connected to contaminate undercooked hamburger patties in U.S. (Riley et al., 1983).

Pathogenic E. coli O157:H7 is frequently found in various environment including, food (Hancock et al., 1994; Cagney et al., 2004), livestock (Elder et al., 2000; Johnsen et al., 2001), soil (Ibekwe et al., 2014) and manure (Franz et al., 2007). Cattle act as the main reservoir of E. coli $\mathrm{O} 157: \mathrm{H} 7$ (Bach et al., 2002) while intermittently and seasonally shed the organism in faeces (Chapman, 2000). The majority of the human E. coli $\mathrm{O} 157: \mathrm{H} 7$ cases were due to food and water contaminated with cattle faecal matter (Gyles, 2007). Recent E. coli O157:H7 outbreaks were linked to undercooked ground beef (King et al., 2014; Torso et al., 2015), beef products (CDC, 2016), ground bison (Cronquist, 2014), pork (Cheng, 2015; Honish, 2017), raw milk (Logsdon et al., 2015), bagged salad (Marder et al., 2014), romaine lettuce (Slayton et al., 2013), spinach (Sharapov et al., 2016) and strawberies (Laidler et al., 2013).

People from any age group can be affected by E. coli $\mathrm{O} 157: \mathrm{H} 7$ infection; while old people and young children can be more susceptible (Codex Alimentarius Committee, 2002). The initial clinical symptoms of $E$. coli $\mathrm{O} 157: \mathrm{H} 7$ infection includes abdominal cramps, non-bloody diarrhoea and more than $70 \%$ of the cases subsequently lead to bloody diarrhoea (Bell et al., 1994). While some cases result in hemorrhagic colitis (grossly bloody diarrhoea) and hemorrhagic uremic syndrome (HUS) a systemic condition associated with acute or chronic kidney failure, thrombotic thrombocytopenic purpura (TTP) and neurological sequelae (Nataro and Kaper, 1998). The ultimate consequence of above complications can be an end-stage renal disease (ESRD) which is a severe chronic form that leads to death (Nataro and Kaper, 1998).

Low infective dose as 10-100 cells (Griffin and Tauxe, 1991; Nataro and Kaper, 1998; Harris et al., 2003), stress resistance mechanisms (Price et al., 2004) and production of toxins (Meng et al., 2007) contribute to the severity of the E. coli $\mathrm{O} 157: \mathrm{H} 7$ infection. Further, efficient acid resistant methods facilitate survival and colonisation of the organism under the low acidic conditions in the gastrointestinal tract (Price et al., 2004) and food with low pH value
(Weagant et al., 1994; Price et al., 2004). Therefore, E. coli $\mathrm{O} 157: \mathrm{H} 7$ is considered as a serious threat to consumers (Kaper et al., 2004; Meng et al., 2007).

Undercooking, cross contamination, improper storage and handling can lead to contamination of food commodities with pathogenic organisms (Panisello et al., 2000; Elexson et al., 2017; New et al., 2017). Therefore, farm to fork investigation facilitates implementation of effective and efficient control measures. The quantitative microbial risk assessment (QMRA) is a scientific and systematic approach that can be used to quantify the risk associated with hazards at the various steps in the production process (Covello and Merkhofer, 1993). Previously, QMRA has been developed for Salmonella enterica serovar Enteriditis in pasteurised liquid eggs (Whiting et al., 1997), E. coli O157: H7 in ground beef hamburgers (Cassin et al., 1998) and Campylobacter in chicken meals (Pouillot et al., 2012).

To date, no such model has been developed to estimate the human health risks associated with $E$. coli O157: H7 within Malaysia. Hence, this study investigated the prevalence of E. coli $\mathrm{O} 157: \mathrm{H} 7$ in raw beef samples and the generated quantitative data was used to develop a QMRA for E. coli O157:H7. This paper reports the first risk assessment model of E. coli O157: H7 linked to the consumption of beef in Malaysia.

\section{Materials and methods}

\subsection{Sample collection}

A total of 99 samples of imported beef $(n=$ 27) from the supermarket and local beef from the supermarket $(n=34)$ and night market $(n=38)$ were purchased randomly from a supermarkets and night market in Selangor, Malaysia. Samples were collected into sterile plastic bags and analysed immediately upon arrival at the laboratory.

\subsection{Most probable number (MPN) method}

In a sterile stomacher bag, $10 \mathrm{~g}$ of sample was added with $90 \mathrm{ml}$ of Tryptic Soy Broth (TSB; Bacto, France) and homogenised for $60 \mathrm{~s}$. The mixture was incubated at $37^{\circ} \mathrm{C}$ for $24 \mathrm{~h}$. To perform the MPN, 100fold and 1000-fold dilutions of the stomacher fluids were prepared. One $\mathrm{ml}$ aliquot from each dilution was removed into triplicate MPN tubes; next tubes were incubated at $37^{\circ} \mathrm{C}$ for $24 \mathrm{~h}$. The positive MPN tubes were then subjected to PCR for the detection of $r f b \mathrm{O} 157$ and $f l i c \mathrm{H} 7$ genes specific for E. coli O157:H7. 


\subsection{DNA extraction and PCR amplification}

MPN tubes showing visible turbidity were used for DNA extraction using a modified boil cell method. Briefly, $1 \mathrm{~mL}$ of aliquot from each MPN tube was centrifuged at $12,000 \times \mathrm{g}$ for $3 \mathrm{~min}$. The pellet was resuspended in $500 \mu \mathrm{L}$ of TE buffer and after mixing was boiled for $10 \mathrm{~min}$. Boiled mixture was cooled at $-20^{\circ} \mathrm{C}$ for $10 \mathrm{~min}$ and centrifuged at $12,000 \times \mathrm{g}$ for $5 \mathrm{~min}$. Final supernatant was used as a template for PCR amplification. $r f b \mathrm{O} 157$ and flic $\mathrm{H} 7$ genes were detected by multiplex PCR. The sequence of the two primer pairs was shown in Table 1. The $r f b \mathrm{O} 157$ primer is specific for somatic antigen (O157) and flic $\mathrm{H} 7$ primer is specific for the flagellar antigen (H7).

PCR amplification was performed in a $25 \mu \mathrm{L}$ reaction mixture consisting of $5 \mu 1$ of $5 \mathrm{x}$ PCR buffer, $0.5 \mu \mathrm{l}$ of deoxynucleoside triphosphate $(10 \mathrm{mM})$, $2 \mu \mathrm{l}$ of $\mathrm{MgCl}_{2}(25 \mathrm{mM}), 0.2 \mu \mathrm{l}$ of Taq polymerase $(5 \mathrm{U} / \mu \mathrm{L}), 2 \mu \mathrm{l}$ of DNA template and $1.25 \mu \mathrm{l}$ of each primer $(0.5 \mu \mathrm{M})$. The thermal cycling started with pre-denaturation at $94^{\circ} \mathrm{C}$ for $2 \mathrm{~min}$, followed by 35 cycles of 1 min denaturation at $94^{\circ} \mathrm{C}, 1$ min primer annealing at $55^{\circ} \mathrm{C}, 1 \mathrm{~min}$ elongation at $72^{\circ} \mathrm{C}$, and the final extension at $72^{\circ} \mathrm{C}$ for $10 \mathrm{~min}$. Amplified products were electrophoresed on $1.0 \%$ agarose gel at $100 \mathrm{~V}$ for $30 \mathrm{~min}$. PCR products were visualised under UV light after staining with ethidium bromide. The expected sizes of amplicons for $r f b \mathrm{O} 157$ and flic $\mathrm{H} 7$ genes were $259 \mathrm{bp}$ and $625 \mathrm{bp}$ respectively.

\subsection{Risk assessment}

\subsubsection{Statement of purpose}

The objective of this primary risk assessment is to estimate the probability of infection due to consumption of E. coli $\mathrm{O} 157: \mathrm{H} 7$ contaminated beef. Data generated from the hazard identification, exposure assessment and hazard characterization were used to estimate the risk.

A conceptual model was developed conduct the risk assessment and the @risk Version 7.5 software package (Palisade Corporation, USA) together with Microsoft Excel was applied to run the simulations. The Monte Carlo simulation was adopted to estimate probabilities by performing a total of 100,000 iterations for simulation. The output of this risk assessment was the probability of human E. coli infection associated with consumption of beef. All the variables and probability distributions used for this quantitative risk assessment were presented in Table 2.

\subsubsection{Exposure assessment}

The risk assessment of E. coli $\mathrm{O} 157: \mathrm{H} 7$ was conducted separately to assess the risk associated with consumption of beef purchased from hypermarket A, $\mathrm{B}$ and wet market.

Table 1. Primer sequences for the detection of Escherichia coli $\mathrm{O} 157: \mathrm{H} 7$ using a multiplex PCR

\begin{tabular}{|c|c|c|c|c|}
\hline Primers & Primer sequence (5' to $\left.3^{\prime}\right)$ & Target gene & Amplicon size & Reference \\
\hline flic $\mathrm{H} 7-\mathrm{F}$ & GCG CTG TCG AGT TCT ATC GAG & flic $\mathrm{H} 7$ & $625 \mathrm{bp}$ & Sarimehmetoglu et al., 2009 \\
\hline flicH7-R & CAA CGG TGA CTT TAT CGC CAT TCC & & & \\
\hline$r f b \mathrm{O} 157-\mathrm{F}$ & CGG ACA TCC ATG TGA TAT GG & rfbO157 & $259 \mathrm{bp}$ & Jamshidi et al., 2008 \\
\hline$r f b \mathrm{O} 157 \mathrm{R}$ & TTG CCT ATG TAC AGC TAA TCC & & & \\
\hline
\end{tabular}

Table 2. Description of parameters and distributions in the model for exposure assessment of E. coli $\mathrm{O} 157: \mathrm{H} 7$

\begin{tabular}{|c|c|c|}
\hline Variable & Description & Distribution \\
\hline$P_{\text {prev }}$ & Prevalence of $E$. coli $\mathrm{O} 157: \mathrm{H} 7$ at retail & $\operatorname{Beta}(s+1, n-s+1)$ \\
\hline $\mathrm{C}_{\text {conc }}$ & Concentration of $E$. coli $\mathrm{O} 157: \mathrm{H} 7$ at retail & Pert (min, med, max) \\
\hline $\mathrm{L}_{\text {cont }}$ & Level of $E$. coli $\mathrm{O} 157: \mathrm{H} 7$ contamination at retail & Discrete $\left(\mathrm{P}_{\text {prev }}, \mathrm{C}_{\text {conc }}\right)$ \\
\hline $\mathrm{H}_{\text {temp }}$ & Holding temperature & Triangle (min, med, max) \\
\hline $\mathrm{H}_{\text {time }}$ & Holding time duration & Triangle (min, med, max) \\
\hline $\mathrm{N}_{\max }$ & Maximum density population & $\operatorname{MAX}\left(\operatorname{Normal}\left(\left(\mathrm{L}_{\text {cont }}+\mathrm{kX} \mathrm{H}_{\text {time }}\right), \operatorname{SQRT}\left(\left(\mathrm{L}_{\text {cont }}+\mathrm{kX} \mathrm{H}_{\text {time }}\right)\right)\right)\right)$ \\
\hline $\mathrm{T}_{\text {cook }}$ & Cooking time & Triangle (min, med, max) \\
\hline$A_{\text {serv }}$ & Serving amount & $\operatorname{Normal}(\mu, \sigma)$ \\
\hline
\end{tabular}




\subsubsection{Retail beef}

The initial prevalence of E. coli O157:H7 contamination $\left(\mathrm{P}_{\text {prev }}\right)$ in beef was characterised as a Beta $(\mathrm{s}+1, \mathrm{n}-\mathrm{s}+1)$ distribution in @risk. The concentrations of E. coli O157:H7 ( $\left.\mathrm{C}_{\text {conc }}\right)$ in beef was estimated using a PERT distribution where included the minimal, the median and the maximal value of E. coli $\mathrm{O} 157: \mathrm{H} 7$ concentration in $\log \mathrm{MPN} / \mathrm{g}$ data generated from this study. The level of E. coli O157:H7 contamination $\left(\mathrm{L}_{\text {cont }}\right)$ at retail was estimated as a discrete distribution (Table 2).

\subsubsection{Holding time of beef at home}

Bacterial growth can occur during the time period between retail to consumption. Estimated data on home storage duration $\left(\mathrm{H}_{\text {time }}\right)$ and temperature $\left(\mathrm{H}_{\text {temp }}\right)$ of beef at Malaysian household level were fitted by using triangular distribution. The growth rate of E. coli $\mathrm{O} 157: \mathrm{H} 7$ was calculated using the below equation.

$$
\mathrm{k}=\alpha\left(\mathrm{T}-\mathrm{T}_{\min }\right)^{1.5}
$$

In which $\mathrm{k}$ is the growth rate of bacteria (log $\mathrm{MPN} / \mathrm{g}$ ) as a function of $\mathrm{T}$ is the holding temperature, $\mathrm{T}_{\min }$ is the minimum temperature and $\alpha$ is a constant. The maximum population density with storage $\left(\mathrm{N}_{\max }\right)$ was modelled as a normal distribution using the square root value of the level of $E$. coli $\mathrm{O} 157: \mathrm{H} 7$ contamination $\left(\mathrm{L}_{\text {cont }}\right)$ at retail, bacterial growth rate (k) and on home storage duration $\left(\mathrm{H}_{\text {time }}\right)$.

\subsubsection{Cooking}

The cooking duration of beef by Malaysian was based on expert opinion and used as input data to estimate cooking time $\left(\mathrm{T}_{\text {cook }}\right)$ using triangular distribution. The reduction of E. coli $\mathrm{O} 157: \mathrm{H} 7$ in beef during cooking was based upon the following equation.

$$
\mathrm{C}_{\text {cook }}=\left(-\mathrm{T}_{\text {cook }} / \mathrm{D}\right)+\left(\mathrm{N}_{\max }\right)
$$

Where $\mathrm{C}_{\text {cook }}$ corresponds to bacteria present after cooking and D represents the D-value 0.2 minutes at $70^{\circ} \mathrm{C}$.

\subsubsection{Serving}

The concentration of E. coli $\mathrm{O} 157: \mathrm{H} 7$ per serving was estimated by multiplying the serving amount $\left(\mathrm{A}_{\text {serv }}\right)$ and concentration of the bacteria present after cooking $\mathrm{C}_{\text {cook }}$. The serving amount $\left(\mathrm{A}_{\text {serv }}\right)$ was estimated by incorporating into a normal distribution.

\subsubsection{Direct cross contamination to hand}

To estimate the cross contamination $\left(\mathrm{C}_{\text {hand }}\right)$ of $E$. coli $\mathrm{O} 157: \mathrm{H} 7$, multiplied the transfer rate (Rtran) either by level of $E$. coli $\mathrm{O} 157: \mathrm{H} 7$ contamination $\left(\mathrm{L}_{\text {cont }}\right)$ at retail in exposure pathway 01 or maximum population density with storage $\left(\mathrm{N}_{\max }\right)$ in exposure pathway 02 . Transfer rate $\left(\mathrm{R}_{\text {tran }}\right)$ was adopted from previous studies.

\subsubsection{Hazard characterization}

An exponential model was used to calculate the probability of infection $\left(\mathrm{P}_{\text {inf }}\right)$ following exposure to E. coli $\mathrm{O} 157: \mathrm{H} 7$.

$$
\mathrm{P}_{\mathrm{inf}}=1-\exp (-\mathrm{rN})
$$

In which, $\mathrm{P}_{\text {inf }}$ corresponds probability of infection, $\mathrm{N}$ is the number of pathogens per exposure, and $\mathrm{r}$ is an exponential dose-response relationship. Acute gastroenteritis, fever, abdominal cramps are some of the common symptoms associated with E. coli O157:H7 infection (Bell et al., 1994).

\subsubsection{Risk characterization}

The final result of a risk assessment model is the risk characterization, in which combines exposure assessment and hazard characterization to estimate the probability of an adverse effect in a known population resultant due to the hazard (Schlundt et al., 2004). The probability of acquiring E. coli O157:H7 infection $\left(\mathrm{N}_{\text {inf }}\right)$ by Malaysians was estimated by the equation given below.

$$
\mathrm{N}_{\text {inf }}=\mathrm{P}_{\text {inf }} X \mathrm{P}_{\text {cons }}
$$

Considered that Malaysian population was 30,000,000 (Department of Statistics Malaysia, 2013) and consumer data $\left(\mathrm{P}_{\text {cons }}\right)$ from Malaysian health ministry was used to calculate the exposed population (Ministry of Health, 2003).

\section{Results}

\subsection{Prevalence}

The prevalence level of E. coli $\mathrm{O} 157: \mathrm{H} 7$ in beef samples collected from various retail dwellings including hypermarket and wet market were given in Table 3. Overall, E. coli $\mathrm{O} 157: \mathrm{H} 7$ was isolated 54 (54.54\%, CI: $49.54,59.54)$ out of 99 beef samples with a concentration ranging from 3- $1100 \mathrm{MPN} / \mathrm{g}$. Among the markets, highest E. coli O157:H7 
prevalence of $89.5 \%$ (34 out of 38 ) was detected in beef samples from the wet market. While $E$. coli $\mathrm{O} 157: \mathrm{H} 7$ was positive in $35.3 \%$ and $20 \%$ beef samples from hypermarket A and B respectively.

Table 3. Prevalence of $E$. coli $\mathrm{O} 157: \mathrm{H} 7$ in beef

\begin{tabular}{lcccc}
\hline Place & $\begin{array}{c}\text { Number } \\
\text { of } \\
\text { samples }\end{array}$ & $\begin{array}{c}\text { Prevalence } \\
\text { rate }(\%)\end{array}$ & $95 \% \mathrm{CI}^{\mathrm{a}}$ & $\begin{array}{c}\text { MPN } \\
\text { range } \\
\text { (MPN/g) }\end{array}$ \\
\hline $\begin{array}{l}\text { Hypermarket } \\
\text { A }\end{array}$ & 51 & 35.30 & $28.61,41.99$ & $3-1100$ \\
Hypermarket & 10 & 20.0 & $7.35,32.65$ & $3-93$ \\
B & & & & \\
Wet market & 38 & 89.50 & $84.52,94.48$ & $3-240$ \\
\hline Total & 99 & 54.54 & $49.54,59.54$ & \\
\hline
\end{tabular}

All 27 samples of imported beef were obtained from hypermarkets while 72 samples of local beef were collected from both wet market $(n=38)$ and hypermarkets $(\mathrm{n}=34)$. In the present study, $18.5 \%$ imported beef harboured E. coli O157:H7 and prevalence in local beef samples from wet market and hypermarkets were positive at $89.5 \%$ and $44.1 \%$, respectively (Figure 1).

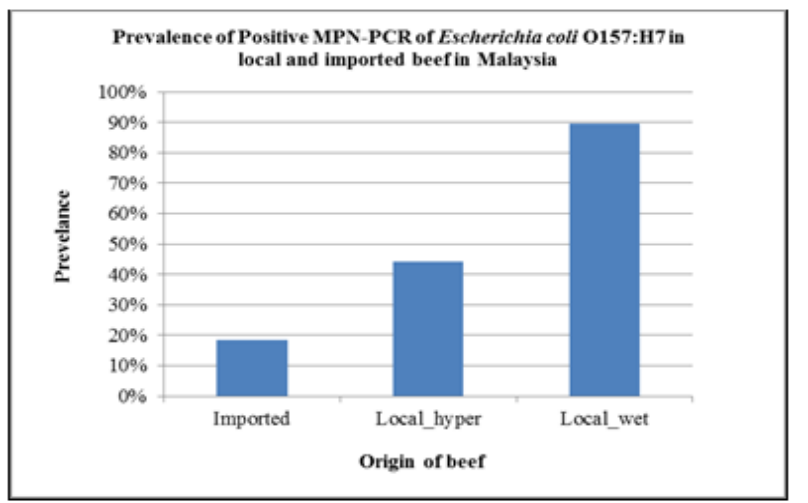

Figure 1. Origin of the E. coli O157:H7 contaminated beef samples

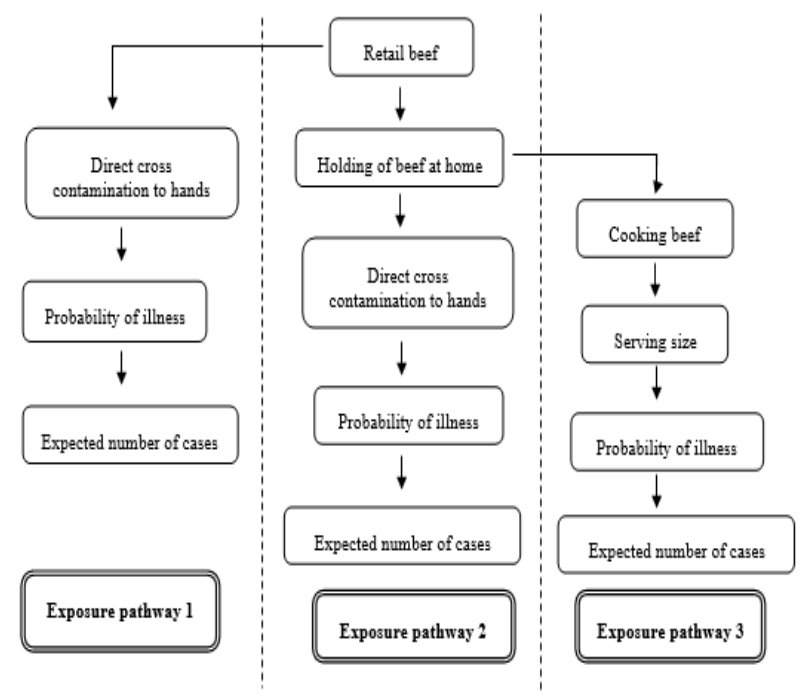

Figure 2. A conceptual model for risk assessment of E. coli O157:H7 in beef

\subsection{Risk estimation}

The present study can be identified as the first quantitative risk assessment intended to estimate the likelihood of acquiring E. coli $\mathrm{O} 157: \mathrm{H} 7$ infection by Malaysians with consumption of beef. A conceptual model as outlined in Figure 2 was developed considering exposure pathways to E. coli $\mathrm{O} 157: \mathrm{H} 7$, on which the risk assessment was conducted.

The model assumed that $E$. coli $\mathrm{O} 157: \mathrm{H} 7$ can be transmitted to humans via three different exposure routes. In exposure pathway, one considers direct contamination of pathogen via raw beef from retail, while the exposure 2 and 3 consider the growth of bacteria during home storage. The risk associated with beef was estimated based on the above exposure routes and according to the retail market type (Table 4).

Table 4. Risk estimation of $E$. coli $\mathrm{O} 157: \mathrm{H} 7$ in beef

\begin{tabular}{lccc}
\hline \multicolumn{1}{c}{ Parameter } & $\begin{array}{c}\text { Hypermarket } \\
\text { A }\end{array}$ & $\begin{array}{c}\text { Hypermarket } \\
\text { B }\end{array}$ & $\begin{array}{c}\text { Wet } \\
\text { market }\end{array}$ \\
\hline $\begin{array}{l}\text { Level (Log MPN/g) } \\
\text { Annual probability of }\end{array}$ & 1.97 & 1.53 & 1.15 \\
illness-exposure 1 & $2.28 \mathrm{E}-04$ & $2.26 \mathrm{E}-04$ & $2.24 \mathrm{E}-04$ \\
$\begin{array}{l}\text { Annual expected } \\
\text { cases- exposure 1 }\end{array}$ & 419 & 415 & 412 \\
$\begin{array}{l}\text { Annual probability of } \\
\text { illness- exposure } 2\end{array}$ & $2.30 \mathrm{E}-04$ & $2.28 \mathrm{E}-04$ & $2.26 \mathrm{E}-04$ \\
$\begin{array}{l}\text { Annual expected } \\
\text { cases- exposure } 2\end{array}$ & 424 & 420 & 416 \\
$\begin{array}{l}\text { Annual probability of } \\
\text { illness- exposure } 3\end{array}$ & $9.97 \mathrm{E}-01$ & $8.84 \mathrm{E}-01$ & $5.93 \mathrm{E}-01$ \\
$\begin{array}{l}\text { Annual expected } \\
\text { cases- exposure } 3\end{array}$ & $1.83 \mathrm{E}+06$ & $1.63 \mathrm{E}+06$ & $1.09 \mathrm{E}+06$ \\
\hline
\end{tabular}

The Monte Carlo simulation conducted using the@Risk software, defined various levels of contamination with probability distributions. According to the calculations, the mean contamination level was 1.97 and $1.53 \mathrm{MPN} / \mathrm{g}$ beef from hypermarket $\mathrm{A}$ and $\mathrm{B}$ respectively. While the lowest level of contamination $(1.15 \mathrm{MPN} / \mathrm{g})$ was detected in beef from the wet market. Though the highest prevalence of $E$. coli $\mathrm{O} 157: \mathrm{H} 7$ was detected in wet markets, the concentration was the lowest comparative to other markets. The level of contamination was simulated as a discrete distribution of concentration and prevalence.

The dose-response model estimated the probability of illness per serving and multiplied by estimated 365 servings per year to compute the annual probability of illness. The annual likelihood of illness ranged from 2.24E-04 to 2.28E-04 for the exposure route 1 for beef from three markets. The highest probability of illness (2.30E-04) for exposure 
route 2 was reported for beef from hypermarket A. Overall probability of illness was highest in the exposure route 3 , of which beef products from hypermarket A resulted in the highest (9.97E-01) number of diseases.

According to the estimates of the consumer data of $\mathrm{MOH}$, Malaysia (2003), that $61.29 \%$ of the population consumed beef and that calculated to be $18,387,000$ people. With this assumption, the simulation model estimated that annual E. coli O157:H7 cases ranged from 412-419 and 416-424 following exposure to route 1 and 2 respectively. However, the expected number of E. coli O157:H7 cases with consumption of contaminated beef estimated to be $1.09 \mathrm{E}+06,1.63 \mathrm{E}+06$ and $1.83 \mathrm{E}+06$ for beef purchased from the wet market, hypermarket $\mathrm{B}$ and hypermarket A, respectively. The growth of the bacteria in the home storage and serving size may be associated with the high number of cases in exposure route 3 which in comparative to the other exposure methods which only estimated the risk associated with the cross contamination.

\section{Discussion}

E. coli $\mathrm{O} 157: \mathrm{H} 7$ is a zoonotic foodborne disease with a high public health significance and one of the most frequently reported foodborne infections in the world (Newell et al., 2010). The E. coli O157:H7 infection is routinely investigated by the developed countries but not in most of the developing countries. In Africa, South America, and Asia, annually million infant deaths were estimated subsequently to enterohemorrhagic E. coli infection (University of Bradford, 1999). Although beef is a commonly consumed staple food in Malaysia, there are only limited studies conducted to identify the prevalence of E. coli O157:H7.

Previously, Radu et al. (1998) detected E. coli O157:H7 in $36 \%$ of beef samples collected from Malaysia. However, prevalence level of E. coli O157:H7 in ground beef from studies in Argentina (Chinen et al., 2001) and North America (Doyle and Schoeni, 1987) was able to detect only in $3.8 \%$ and $3.7 \%$ respectively. Recently, a study conducted in by Sukhumungoon and colleagues (2011) found a prevalence of STEC in $27 \%$ of buffalo, $23 \%$ of cattle, and $38.5 \%$ of goat meat exported from Malaysia to Thailand. Both locally produced beef and imported beef are available at the retail level in Malaysia. Therefore, beef samples used in this study had imported and local origin.

Certifying the safety of food commodities is the main challenge faced by the local authorities as the safety of food is related to public health and economy of the country (Signorini et al., 2009). Traditional food safety measures based on penalties and withdrawing hazardous food commodities are not feasible for current and emerging food related hazards safety as those methods do not adopt or simulate any precautionary measures. With the introduction of risk analysis, insight into foodborne infections could be comprehended in a more scientific basis and preventive practice methodology (Hoornstra and Notermans, 2001). Risk analysis is a scientific method that evaluates, manage and communicate risk with the assistance of related stakeholders. Based on the outputs of the risk analysis the interested parties and the regulatory authorities can implement control measures to ensure safety (Signorini et al., 2009).

According to the findings, the initial concentration and prevalence of bacteria on beef were key variables in the model output. However, input data generated from this study does not represent the entire Malaysia. According to Gardner (2004), one of the drawbacks of risk assessment process particularly at the exposure assessment is the unavailability of representative data from various researches. Though probability distributions were incorporated to reduce the uncertainty, the estimations cannot be validated. Further, data from farm to fork is necessary to conduct a more robust exposure assessment (Lammerding and Fazil, 2000). In addition, before usage of third party data, the specificity, sensitivity, and reliability of sampling and testing methods should be assessed and should be properly acknowledge (Lammerding and Fazil, 2000).

The relationship between the dose and the response is scalable; the exponential model was used to estimate dose-response (Teunis and Havelaar, 2000). According to the exponential dose- response, probability of illness depends on the exponential dose-response relationship and number of pathogens per exposure. Hence, the precise dose is not necessary to estimate the risk (Teunis et al., 2005). Available developed and validated, dose-response models were established only in developed countries. Therefore, application into local conditions may lead to inaccuracies (Haas and Eisenberg, 2001). Moreover, the current status of the art of QMRA is that this risk assessment method does not account for other factors that could influence the infection such as the degree of immunity of targeted people, or the distribution of infection over time due to the initial exposure (Huang and Haas 2009). The infectivity of E. coli $\mathrm{O} 157: \mathrm{H} 7$ is very low, and the dose-response model can assess the infection even at minute levels of infection or risk which may complement 
epidemiological investigations (Ferrer et al., 2012).

In the current model, influential factors such as level of immunity in the population and probability of infection prior to assessment were considered (Huang and Haas 2009). Availability of local consumer data and incorporation into the model was able to provide a more realistic estimation for expected number of cases in the country, rather than predicting based on data from developed countries. However, further studies are necessary to generate data on local consumer and cooking patterns. In addition, this study evaluated the risk of $E$. coli $\mathrm{O} 157: \mathrm{H} 7$ infection, which can be further categorised based on the type of infection including gastroenteritis, haemolytic uremic syndrome and mortality.

The current risk assessment was conducted with incorporating probability distributions rather than using point estimates. According to previous studies, if reliable data is at available usage for probability distributions, it would be more suitable (Nauta, 2000). Further, the probability distributions can consider the uncertainty associated with the assessment. In spite the limitations of risk assessment modelling; the technique was used to evaluate the risk associated with many aspects including health, water and food safety (WHO 2006; Mataragas et al., 2010). Comparative to epidemiological studies, risk assessment process is less resource demanding and requires a limited amount of financial, personnel and time involvement. Therefore, risk estimation can be generated earlier than the epidemiological studies which may be beneficial in implementing control or preventive strategies.

\section{Conclusion}

In conclusion, the present research work is the first effort in modelling the risk of E. coli O157:H7 infection connected to beef in Malaysia. The developed quantitative risk assessment model quantified and provided understanding into the risk of E. coli $\mathrm{O} 157: \mathrm{H} 7$ infection and indicated that the risk could be controllable at the retail and home levels, especially during food preparation. The model can be used to evaluate the various mitigations options to control the risk of E. coli $\mathrm{O} 157: \mathrm{H} 7$ in beef including food sanitary measures and cooking procedures. With the experiential data collected, this model can be further improved to create microbial risk predictions applicable to Malaysia in the future.

\section{Conflict of interest}

There is no conflict of interest.

\section{Acknowledgements}

The research work was funded by Kakenhi Grant-in-Aid for Scientific Research (KAKENHI 24249038), Japan Society for the Promotion of Sciences and grant-in-aid of Ministry of Health, Labour and Welfare, Japan and in part Fundamental Research Grant Project (FRGS/1/2014/SG05/ UPM/01/2/5524559) from the Ministry of Education, Malaysia.

\section{References}

Bach, S.J., McAllister, T.A., Veira, D.M., Gannon, V.P.J. and Holley, R.A. (2002). Transmission and control of Escherichia coli O157:H7 - A review. Canadian Journal of Animal Science, 82(4), 475- 490.

Bell, B.P., Goldoft, M., Griffin, P.M., Davis, M.A., Gordon, D.C. and Tarr, P.I. (1994). A multistate outbreak of Escherichia coli $\mathrm{O} 157: \mathrm{H7}$ - associated bloody diarrhea and hemolytic uremic syndrome from hamburgers: the Washington experience. Journal of American Medical Association, 272, 1349-1353.

Bell, C. and Kyriakides, A. (1998). E. coli: a Practical Approach to the Organism and its Control in Foods. London: Blackie Academic and Professional.

Beuchat, L.R. (1998). Surface decontamination of fruits and vegetables eaten raw: A review. Geneva: Food Safety Unit, World Health Organization.

Cagney, C., Crowley, H., Duffy, G., Sheridan, J.J., O’brien, S., Carney, E. and Bishop, R.H. (2004). Prevalence and numbers of Escherichia coli O157: H7 in minced beef and beef burgers from butcher shops and supermarkets in the Republic of Ireland. Food Microbiology, 21(2), 203-212.

Cassin, M.H., Lammerding, A.M., Todd, E.C.D., Ross, W. and McColl, R.S. (1998). Quantitative risk assessment for Escherichia coli O157:H7 in ground beef hamburgers. International Journal of Food Microbiology, 41(1), 21-44.

Centers for Disease Control and Prevention (CDC). (2016). Multistate Outbreak of Shiga toxin-producing Escherichia coli O157:H7 Infections Linked to Beef Products Produced by Adams Farm (Final Update). Retrieved on March 13, 2017 from CDC Website: https:/www.cdc.gov/ecoli/2016/o157h7-09-16/index. html

Chapman, P.A. (2000). Sources of Escherichia coli 0157 and experiences over the past 15 years in sheffield, UK. Journal of Applied Microbiology, 88, 51S-60S.

Cheng, J. (2015). When Pigs Fly: A Large Outbreak of $E$. coli O157: H7 Infections Associated with Exposure to Contaminated Pork Products in Alberta, Canada, 2015 CSTE Annual Conference. Alberta, Canada: CSTE. 
Chinen, I., Tamora, J.D., Miliwebsky, E., Lound, L.H., Chillemi, H., Ledri, S., Baschkier, A., Scarpin, M., Manfred, E. and Rivas, M. (2001). Isolation and characterization of Escherichia coli O157:H7 from retail meats in Argentina. Journal of Food Protection, 64, 1346-1350.

Codex Alimentarius Committee (2002). Risk profile for enterohemorragic $E$. coli including the identification of the commodities of concern, including sprouts, ground beef and pork No. CX/FH 03/5-Add.

Covello, V.T. and Merkhofer, M.W. (1993). Risk assessment methods: approaches for assessing health and environmental risks. New York: Plenum Press.

Cronquist, A. (2014). Investigating an Outbreak of E. coli O157: H7 Infections Associated with Ground Bison. Agricultural Outlook Forum 2014 (No. 168330). Washington, DC: United States Department of Agriculture.

Department of Statistics Malaysia. (2013). Demographic Indicator. Putrajaya, Malaysia: Department of Statistics, Malaysia.

Doyle, M.P. and Schoeni, J.L. (1987). Isolation of Escherichia coli O157:H7 from retail fresh meats and poultry. Applied Environmental Microbiology, 53, 2394-2396.

Elexson, N., Nik Yuhanis, F.N., Malcolm, T.T.H., New, C.Y., Chang, W.S., Ubong, A., Kuan, C.H., Loo, Y.Y., Thung, T.Y. and Son, R. (2017). Occurrence of Escherichia coli harbouring stx genes in popiah, a Malaysian street food. Food Research, 1(1), 29 - 32

Elder, R.O., Keen, J.E., Siragusa, G.R., Barkocy-Gallagher, G.A., Koohmaraie, M. and Laegreid, W. W. (2000). Correlation of enterohemorrhagic Escherichia coli O157 prevalence in feces, hides, and carcasses of beef cattle during processing. Proceedings of the National Academy of Sciences, 97(7), 2999-3003.

Ferrer, A., Nguyen-Viet, H. and Zinsstag, J. (2012). Quantification of diarrhea risk related to wastewater contact in Thailand. EcoHealth, 9(1), 49-59.

Franz, E., Klerks, M.M., De Vos, O.J., Termorshuizen, A.J. and van Bruggen, A.H. (2007). Prevalence of Shiga toxin-producing Escherichia coli stx1, stx2, eaeA, and $r f b \mathrm{E}$ genes and survival of $E$. coli $\mathrm{O} 157: \mathrm{H} 7$ in manure from organic and low-input conventional dairy farms. Applied and Environmental Microbiology, 73(7), 2180-2190.

Gardner, I.A. (2004). An epidemiologic critique of current microbial risk assessment practices: the importance of prevalence and test accuracy data. Journal of Food Protection, 67(9), 2000-2007.

Griff, P.M. and Boyce, T.G. (1998). Escherichia coli O157:H7. In Scheld, W. M., Armstrong, D., and Hughes, J.M. (Eds). Emerging Infections, p. 137-145. Washington, DC: ASM Press

Griffin, P.M. and Tauxe, R.V. (1991). The epidemiology of infections caused by Escherichia coli $\mathrm{O} 157: \mathrm{H} 7$, other enterohemorrhagic E. coli and the associated hemolytic uremic syndrome. Epidemiology Reviews, 13, 60-98.
Gyles, C.L. (2007). Shiga toxin-producing Escherichia coli: an overview. Journal of Animal Science, 85(E. Suppl.), E45-E62.

Haas, C. and Eisenberg, J.N.S. (2001). Risk assessment. In Petrel, L. and Bartram, J. (Eds). Water Quality: Guidelines, Standards and Health, p. 161-183. London: IWA Publishing.

Hancock, D.D., Besser, T.E., Kinsel, M.L., Tarr, P.I., Rice, D.H. and Paros, M.G. (1994). The prevalence of Escherichia coli O157. H7 in dairy and beef cattle in Washington State. Epidemiology and Infection, 113(02), 199-207.

Honish, L. (2017). Escherichia coli O157: H7 Infections Associated with Contaminated Pork ProductsAlberta, Canada, July-October 2014. Morbidity and Mortality Weekly Report, 65.

Hoornstra, E. and Notermans, S. (2001). Quantitative microbiological risk assessment. International Journal of Food Microbiology, 66(1-2), 21-29.

Huang, Y. and Haas, C.N. (2009) Time-dose-response models for microbial risk assessment. Risk Analysis, 29, 648-661.

Ibekwe, A.M., Ma, J., Crowley, D.E., Yang, C.H., Johnson, A.M., Petrossian, T.C. and Lum, P.Y. (2014). Topological data analysis of Escherichia coli O157: H7 and non-O157 survival in soils. Frontiers in Cellular and Infection Microbiology, 4.

Jamshidi, A., Bassami, M. R. and Rasooli, M. (2008). Isolation of Escherichia coli O157: $\mathrm{H} 7$ from ground beef samples collected from beef markets, using conventional culture and polymerase chain reaction in Mashhad, northeastern Iran. Iranian Journal of Veterinary Research, 9(1), 72-76.

Johnsen, G., Wasteson, Y., Heir, E., Berget, O.I. and Herikstad, H. (2001). Escherichia coli O157: H7 in faeces from cattle, sheep and pigs in the southwest part of Norway during 1998 and 1999. International Journal of Food Microbiology, 65(3), 193-200.

Kaper, J.B., Nataro, J.P. and Mobley, H.L. (2004). Pathogenic Escherichia coli. Nature Reviews Microbiology, 2, 123-140.

King, L.A., Loukiadis, E., Mariani-Kurkdjian, P., Haeghebaert, S., Weill, F. X., Baliere, C. and Callon, H. (2014). Foodborne transmission of sorbitolfermenting Escherichia coli O157:[H7] via ground beef: an outbreak in northern France, 2011. Clinical Microbiology and Infection, 20(12), O1136-O1144.

Laidler, M.R., Tourdjman, M., Buser, G.L., Hostetler, T., Repp, K.K., Leman, R. and Keene, W.E. (2013). Escherichia coli O157:H7 infections associated with consumption of locally grown strawberries contaminated by deer. Clinical Infectious Diseases, 57(8), 1129-1134.

Lammerding, A.M. and Fazil, A. (2000). Hazard identification and exposure assessment for microbial food safety risk assessment. International Journal of Food Microbiology, 58(3), 147-157.

Lim, V.K.E. (2002). Foodborne diseases in Malaysia. Medical Journal of Malaysia, 57(1), 1-2. 
Logsdon, J., Vaughn, T., Rush, C., Grooms, W.J., Tobias, J., Brawley, R. and Poe, J. (2015). E. coli O157: H7 Outbreak Associated with Consumption of Unpasteurized Milk. 2015 CSTE Annual Conference. Kentucky: CSTE.

Marder, E.P., Garman, K.N., Ingram, L.A. and Dunn, J.R. (2014). Multistate outbreak of Escherichia coli O157: H7 associated with bagged salad. Foodborne Pathogens and Disease, 11(8), 593-595.

Mataragas, M., Zwietering, M.H., Skandamis, P.N. and Drosinos, E.H. (2010). Quantitative microbiological risk assessment as a tool to obtain useful information for risk managers - specific application to Listeria monocytogenes and ready-to-eat meat products. International Journal of Food Microbiology, 141(Supp11), S170- S179.

Meng, J., Doyle, M.P., Zhao, T. and Zhao, S. (2007). Enterohemorrhagic Escherichia coli. In Doyle, M.P. and Beuchat, L.R. (Eds). Food Microbiology: Fundamentals and Frontiers. 3rd ed. Washington, DC: ASM Press.

Ministry of Health (MOH) Malaysia. (2003). Malaysian Adult Nutrition Survey 2003: Habitual Food Intake of Adults Aged 18 to 59 years, 7. Malaysia: Ministry of Health Malaysia.

Ministry of Health (MOH), Malaysia. (2016). Health facts. Retrieved on February 28, 2017 from MOH Website: http://www.moh.gov.my/images/gallery/publications/ KKM\%20HEALTH\%20FACTS\%202016.pdf

Nataro, J.P. and Kaper, J.B. (1998). Diarrheagenic Escherichia coli. Clinical Microbiology Reviews, 11, 142-201.

Nauta, M.J. (2000). Separation of uncertainty and variability in quantitative microbial risk assessment models. International Journal of Food Microbiology, 57(1-2), 9-18.

New, C.Y., Wong, C.Y., Usha, M., Ubong, A., Nakaguchi, Y., Nishibuchi, M. and Son, R. (2017). Level of Campylobacter jejuni from naturally contaminated chicken liver and chicken legs in various task: a cross contamination study. Food Research, 1(2), 33-37.

Newell, D.G., Koopmans, M., Verhoef, L., Duizer, E., Aidara-Kane, A., Sprong, H. and Kruse, H. (2010). Food-borne diseases - the challenges of 20 years ago still persist while new ones continue to emerge. International Journal of Food Microbiology, 139 (Suppl.), S3-15.

Panisello, P.J., Rooney, R., Quantick, P.C. and StanwellSmith, R. (2000). Application of foodborne disease outbreak data in the development and maintenance of HACCP systems. International Journal of Food Microbiology, 59, 221-234.

Pouillot, R., Garin, B., Ravaonindrina, N., Diop, K., Ratsitorahina, M., Ramanantsoa, D. and Rocourt, J. (2012). A Risk Assessment of Campylobacteriosis and Salmonellosis Linked to Chicken Meals Prepared in Households in Dakar, Senegal. Risk Analysis, 32(10), 1798-1819.
Price, S.B.,Wright, J.C., DeGraves, F.J., Castanie-Cornet, M.P. and Foster, J.W. (2004). Acid resistance systems required for survival of Escherichia coli O157:H7 in the bovine gastrointestinal tract and in apple cider are different. Applied Environment Microbiology, 70, 4792-4799.

Radu, S., Mutalib, S.A. and Rusul, G. (1998). Detection of Escherichia coli $\mathrm{O} 157: \mathrm{H7}$ in the beef marketed in Malaysia. Applied and Environmental Microbiology, 64(3), 1153-1156.

Riley, L.W., Remis, R.S., Helgerson, S.D., McGee, H.B., Wwlls, J.G., Davis, B.R., Hebert, R.J., Olcott, E.S., Johnson, L.M., Hargrett, N.T., Blake, P.A. and Cohen, M.L. (1983). Hemorrhagic colitis associated with a rare Escherichia-coli serotype. New England Journal of Medicine, 308(12), 681-685.

Sarimehmetoglu, B., Aksoy, M. H., Ayaz, N. D., Ayaz, Y., Kuplulu, O. and Kaplan, Y. Z. (2009). Detection of Escherichia coli O157: H7 in ground beef using immunomagnetic separation and multiplex PCR. Food Control, 20(4), 357-361.

Sharapov, U.M., Arthur M.W., Jeffrey P.D., William E.K., Jeffrey F., Samir, S. and Hyytia-Trees, E. (2016). Multistate Outbreak of Escherichia coli O157: H7 Infections Associated with Consumption of Fresh Spinach: United States, 2006. Journal of Food Protection, 79(12), 2024-2030.

Signorini, M.L., Marín, V., Quinteros, C. and Tarabla, H. (2009). Hamburger consumption patterns and exposure assessment for verocytotoxigenic Escherichia coli (VTEC): simulation model. Revista Argentina de Microbiologia, 41(3), 168-176.

Slayton, R.B., Turabelidze, G., Bennett, S.D., Schwensohn, C.A., Yaffee, A.Q., Khan, F. and Laufer, A.S. (2013). Outbreak of Shiga toxin-producing Escherichia coli (STEC) O157: H7 associated with romaine lettuce consumption, 2011. PLoS One, 8(2), e55300.

Sukhumungoon, P., Nakaguchi, Y. and Ingviya, N. (2011). Investigation of $\mathrm{stx} 2+$, eae + Escherichia coli O157:H7 in beef imported from Malaysia to Thailand. International Food Research Journal, 18(1), 381-386.

Teunis, P., Van den Brandhof, W., Nauta, M., Wagenaar, J., Van den Kerkhof, H. and Van Pelt, W. (2005). A reconsideration of the Campylobacter dose-response relation'. Epidemiology and Infection, 133(4), 58392.

Teunis, P.F.M. and Havelaar, A.H. (2000). The Beta Poisson model is not a single hit model. Risk Analysis, 20, 511-518.

Torso, L.M., Voorhees, R.E., Forest, S.A., Gordon, A.Z., Silvestri, S.A., Kissler, B. and Mertz, K.J. (2015). Escherichia coli O157: H7 outbreak associated with restaurant beef grinding. Journal of Food Protection, 78(7), 1272-1279.

University of Bradford. (1999). Annual report research. Retrieved on February 24, 2017 from Bradford Website: Www.brad.ac.uk/admin/recruitment/ annrept/1999/research/child.html 
Weagant, S.D., Bryant, J.L. and Bark, D.H. (1994). Survival of Escherichia coli O157:H7 in mayonnaise and mayonnaise-based sauces at room and refrigerated temperatures. Journal of Food Protein, 57, 629-631.

Whiting, R.C. and Buchanan, R.L. (1997). Development of a quantitative risk assessment model for Salmonella enteritidis in pasteurized liquid eggs. International Journal of Food Microbiology, 36, 111-125.

Woodward, D.L., Clark, C.G., Caldeira, R.A., Ahmed, R. and Rodgers, F.G. (2002). Verotoxigenic Escherichia coli (VTEC): A major public health threat in Canada. The Canadian Journal of Infectious Diseases, 13(5), 321-330.

World Health Organisation. (WHO). (2006). Guidelines for the safe use of wastewater, excreta and greywater, Geneva: World Health Organization. 